\title{
'HESS-BREZOWSKY' ATMOSPHERIC CLASSIFICATION TYPES ASSOCIATED WITH NAO AND AO PHASES IN THE NORTHERN PART OF MOLDOVA
}

\author{
Ilie Nicolae ${ }^{1,2}$, Axinte Aurel-Dănuțț ${ }^{1}$ Apostol Liviu ${ }^{2}$ \\ ${ }^{1}$ Unit of Hail Suppression Moldova 1 Iasi, Romania; nyycu_87@yahoo.com; \\ axinte_dan@yahoo.com \\ ${ }^{2}$ Alexandru Ioan Cuza, University of Iași, Faculty of Geography and Geology, Iași, \\ Romania; apostolliv@yahoo.com
}

Keywords: Omega ridge; Hess-Brezowsky; North Atlantic Oscillation; Arctic Oscillation; extreme weather

\begin{abstract}
The North Atlantic Oscillation (NAO) and that Artic (AO), respectively, are by considerable importance to make the short-time weather forecast (until three days), followed by those of middle range and long time (until two weeks).

To analyzing the 'Hess-Brezowsky' weather patterns associated with the NAO and AO during 19 years (2000 to 2018), has highlighted some aspects over the weather kind in the north part of Moldova. The zonal air-masses' movements such as northwestern and western, both of them into the anti-cyclonic and cyclonic regime, were deployed in a predominately positive phase of NAO and AO. In the case of NWA type, NAO was 0.17 and AO 0.60, and for WA, NAO was 0.12 and AO 0.71. From NWZ, the NAO shown values around of 0.03 and AO 0.08. Exceptionally, NAO was into a negative phase in the case of $\mathrm{WZ}$, with a value of around -0.13 . Instead,

for WZ, the AO was positive, with a yearly average of 0.08 . Such air-masses movements are associated with a mild weather pattern, especially during the wintertime. Then, over the southern part of Europe, it's set up the 'Omega' ridge. In doing so, the amounts of the precipitations are low at the studied area's level.

By a more significant interest is the southwesterly air-masses movement into a cyclonic regime (SWZ) who shown values of NAO of -0.16 and 00.26 for AO. Also, negative values for NAO were in the case of TRM (Trough over Central Europe), with -0.04 and HNFZ (High over Scandinavia-Iceland, Trough over Central Europe), with -0.64 . For the same synoptically contexts (TRM and HNFZ), the AO was of -0.23 , respectively, -1.31 .

Associated with the negative phases of NAO and AO, the planetary waves have shown an undulatory tendency. In such a case, there are development areas with extreme weather. For the studied region, the negative phases of NAO and AO were associated with severe weather events, such as blizzards, storms, and floods.
\end{abstract}




\section{INTRODUCTION}

The atmospherically dynamic at the Earth's level varies because the warm areas aren't spread equally. In this way, there're take place permanently warm exchanges between low and high latitudes. In this context, when it comes to the Coriolis force, there occurs the baric topography.

The baric gradients (that mean the difference between cyclonic and anticyclonic patterns) give rise to the atmospherically dynamic. By that, the air-masses start to move, when will take place advection by miscellaneous proprieties.

For the middle latitudes (the Euro-Atlantic area), in the wake of the differences in atmospheric pressure, the North Atlantic Oscillation (NAO) occurs. This index plays a key role in Europe's weather level (Hurrell, 1995; van Loon, Rogers, 1978), especially during wintertime. The positive phase of NAO occurs when the Icelandic low-pressure center is lower than usual. At the same time, the subtropical high-pressure center near the Azores tends to be higher than usual. The pressure difference is resulting in a strong westerly at the entire scale of Europe. Also, associated with NAO's positive phases, there can be noticed a northward shift in the general tracks of midlatitude cyclones (Hurrell et al. 2003; Osborn, 2006; Sereze et al. 1997; Wanner et al. 2001).

Thus, precipitations tend to increase over Europe's northern part, and dry conditions occur over Europe's southern part, especially in the Mediterranean Sea. (Lopez-Moreno et al. 2008; Scaife et al. 2005; Trigo et al. 2002; Bartholy, Pongracz, 2009).

Another important parameter within this study is the Arctic Oscillation (AO). The AO is a northern annular mode around the Northern Pole, given by the thermal differences between the middle and polar latitudes. In contrast with NAO, which plays a major role in the European continent (Thompson, Wallace, 1998), AO shows a major interest above the entire northern hemisphere. The AO show three centers of action: one is located over the North Pacific, and the other two are located in the North Atlantic, which has a large projection onto the NAO (Thompson, Wallace, 1998).

This paperwork will be a correlation between the weather's patterns, based on the Hess-Brezowsky (HBGWL) type with NAO and AO, respectively, by the northeastern part of Romania (Northern part of Moldavia).

\section{DATA AND METHODS}

The entire database used in this paperwork was taken from the NOAA (North Ocean and Atmospherically Agency) for the 2000 to 2018 time series. There were used daily data regarding the NAO and AO. There was used daily data because 


\begin{tabular}{|c|c|c|}
\hline \multicolumn{3}{|c|}{ The 29 Grosswetterlagen with English definitions } \\
\hline Type & Indicative & What do they represent \\
\hline \multirow{4}{*}{ West } & WA & Anticyclonic Westerly \\
\hline & $\mathbf{W Z}$ & Cyclonic Westerly \\
\hline & WS & South-Shifted Westerly \\
\hline & WW & Maritime Westerly (Block E. Europe) \\
\hline \multirow{8}{*}{ South } & SWA & Anticyclonic South-Westerly \\
\hline & SWZ & Cyclonic South-Westerly \\
\hline & SA & Anticyclonic Southerly \\
\hline & SZ & Cyclonic Southerly \\
\hline & TB & Low over the British Isles \\
\hline & TRW & Trough over Western Europe \\
\hline & SEA & Anticyclonic South-Easterly \\
\hline & SEZ & Cyclonic South-Easterly \\
\hline \multirow{8}{*}{$\begin{array}{l}\text { North- } \\
\text { westerly } \\
\text { and North }\end{array}$} & NWA & Anticyclonic North-Westerly \\
\hline & NWZ & Cyclonic North-Westerly \\
\hline & NA & Anticyclonic Northerly \\
\hline & NZ & Cyclonic Northerly \\
\hline & HNA & Icelandic High, Ridge C. Europe \\
\hline & HNZ & Icelandic High, Trough C. Europe \\
\hline & HB & High over the British Isles \\
\hline & TRM & Trough over Central Europe \\
\hline \multirow{8}{*}{$\begin{array}{l}\text { North- } \\
\text { easterly } \\
\text { and Est }\end{array}$} & NEA & Anticyclonic North-Easterly \\
\hline & NEZ & Cyclonic North-Easterly \\
\hline & EA & Anticyclonic Easterly \\
\hline & EZ & Cyclonic Easterly \\
\hline & HFA & Scandinavian High, Ridge C. Europe \\
\hline & HFZ & Scandinavian High, Trough C. Europe \\
\hline & HNFA & High Scandinavia-Iceland, Ridge C. Europe \\
\hline & HNFZ & High Scandinavia-Iceland, Trough C. Europe \\
\hline Blocking & HM & High over Central Europe \\
\hline
\end{tabular}

Figure 1. The 29 Grosswetterlagen types 
these can reflect the weather' features, which can occur in short periods, from one to three days. (Feldstein, 2000, Cash, Lee, 2001, Johnson, Feldstein, 2010).

To distinguish the NAO's phases positively or negatively, the aisle between 0.25 to 0.25 was deemed the neutral phase. All the values smaller than -0.25 were linked with the negative phase and those greater than 0.25 with the positive phase. All the values smaller than -0.5 were linked with a negative phase and greater than 0.5 with one positive for AO.

For the study area (the northern part of Moldavia), a classifying of all-weather patterns according to the 'Hess-Brezowsky' Grosswetterlagen (HBGWL) type was made. This is one among more other developed around the world, which means establishing namely weather patterns. Subsequently, based upon these patterns, there'll be building a broad range of weather forecast scenarios.

The Grosswetterlagen (GWL) concept was proposed by Baur et al. (1944), improved upon, and later revised by Hess and Brezowsky $(1952,1969,1977)$, which is one who includes a large area of analyses with very accurate details. This classification is particularly fitted for the central part of Europe. Because the northern and northeastern parts of Romania do a many of the weather's features from Central Europe, I used this concept (HBGWL).

For the entire time-interval took into account (2000 to 2018), there were analyzed the daily synoptically materials provided by www.wetter3.de, regarding the $500 \mathrm{hPa}$ and $1000 \mathrm{hPa}$ geopotential heigh at $00 \mathrm{UTC}$.

The HBGWL includes 29 of the atmospherically types, as shown in fig. 1.

\section{RESULT AND DISCUSION}

\subsection{Annual}

In this paperwork, the atmospheric circulation types at the Central Europe level using the HBGWL and the NAO/AO's phases (negatively, positively, and neutral) have been correlated. The study was undertaken from the annual to the seasonal level. The study period took into account was from January, the $1^{\text {st }} 2000$ to December, the $31^{\text {st }}, 2018$.

By $\mathrm{NAO}+$, there'll prevail the westerlies types. Also, the same feature is linked by $\mathrm{AO}+$.

NAO+ is mainly linked to the following types: HM:0.24, EA:0.25, NEZ:0.24, and NWA:0.24. For AO+, of interest are the follows HM: 0.55, WA:0.75, NA:0.5, NWA:0.6.

The NAO-, by interest types such as: SEZ: -0.28 , TB: -0.58 , HNFZ: -0.63 , HFZ: -0.24 , HNZ: -0.68 , and HNA: -0.6 . For AO-, mainly the types such as: WS: 0.5, TB: -1.3 , SZ: -0.52 , HNFZ: -1.4, HNFA: -1.25 , EZ: -0.5, HNZ: -1.81 , and HNA: -1.3 (fig.2). 
Thus, the westerlies in anti-cyclonic type (NWA, WA), blocking $(\mathrm{HM})$, and even those into the north in the anti-cyclonic type (NA - derived by westerlies, as a result of the 'Coandă' effect, imposed by the Carpathian range's shape, Bordei-Ion - 1988, taken Apostol, Sfî̀că, 2013) are linked by $\mathrm{NAO}+/ \mathrm{AO}+$. Such atmospherical patterns are associated, in many cases, with stable weather, without spectacular weather events, especially, in the wintertime. During the warm season, especially in the summer, there isn't a concrete linkage between $\mathrm{NAO}+/ \mathrm{AO}+$ with special weather events.

A

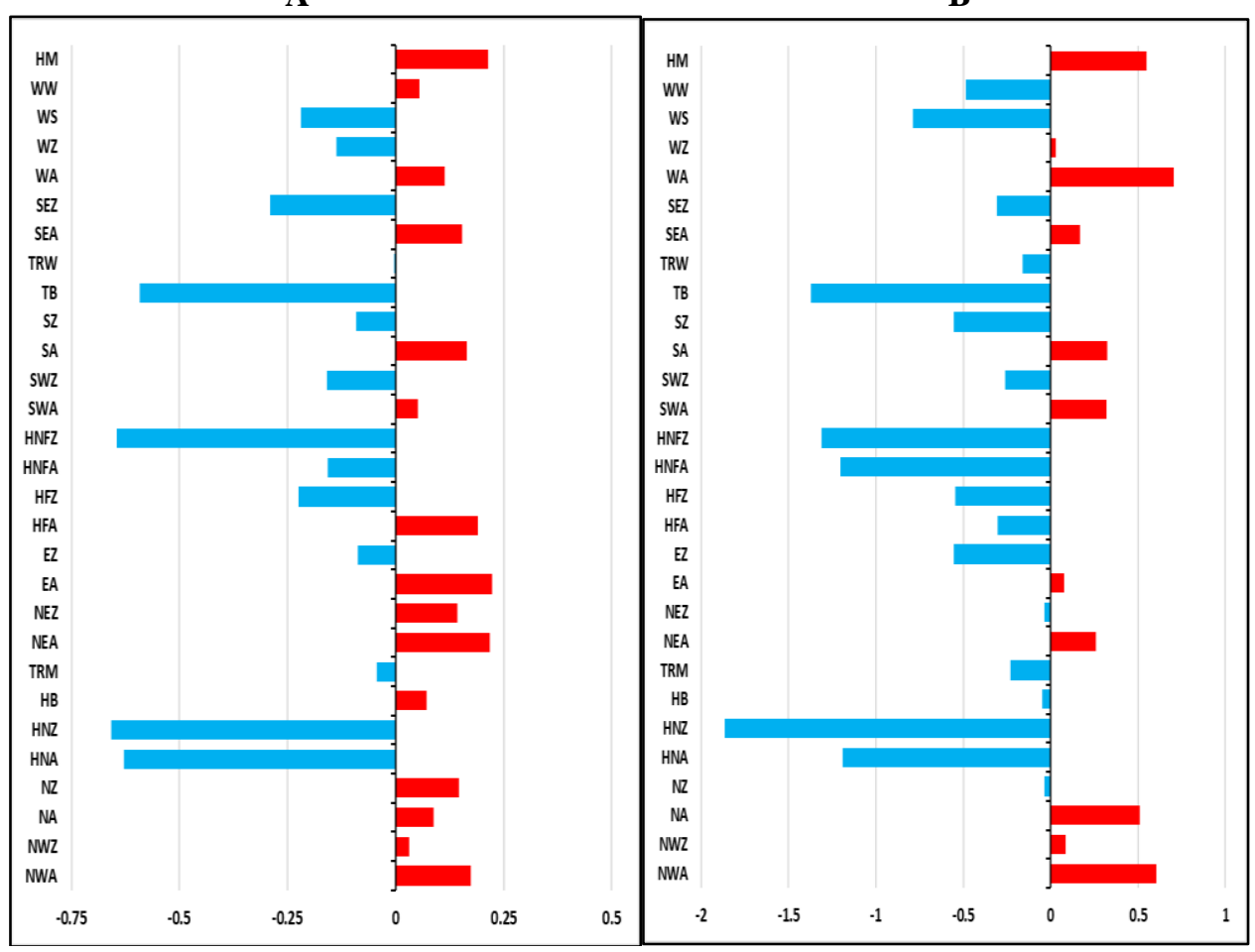

Figure 2. The annual correlation between HBGWL with NAO (A) and AO (B) In the Northern part of Moldavia during the 2000 to 2018 period

Opposingly, the presence of some types such as HNFZ, HFZ, HNZ, and HNA is associated with the NAO-/AO-. In these conditions, the highpressure centers are widely spread over Europe's northern part (the Scandinavian Peninsula) and even in the northeastern part of the North 
Atlantic. No matter the year's period, the synoptic patterns are associated with extreme weather phenomena in the studied area, such as blizzards and snowfalls during the cold semester, and intense rainfalls, and an entire range of severe weather phenomena during the warm semester. Furthermore, the same types are associated with early and late frost occurring in the northeastern part of Moldavia.

To better understand the correlation between HBGWL and positivenegative phases of NAO/AO, a semestrial study was made.

\subsection{Semestrial}

\section{A. Warm semester}

The global warming that occurs during the last decades is associated with a decrease of the Arctic ice-sea extend (Nakamura et al. 2015). The entirely process

A

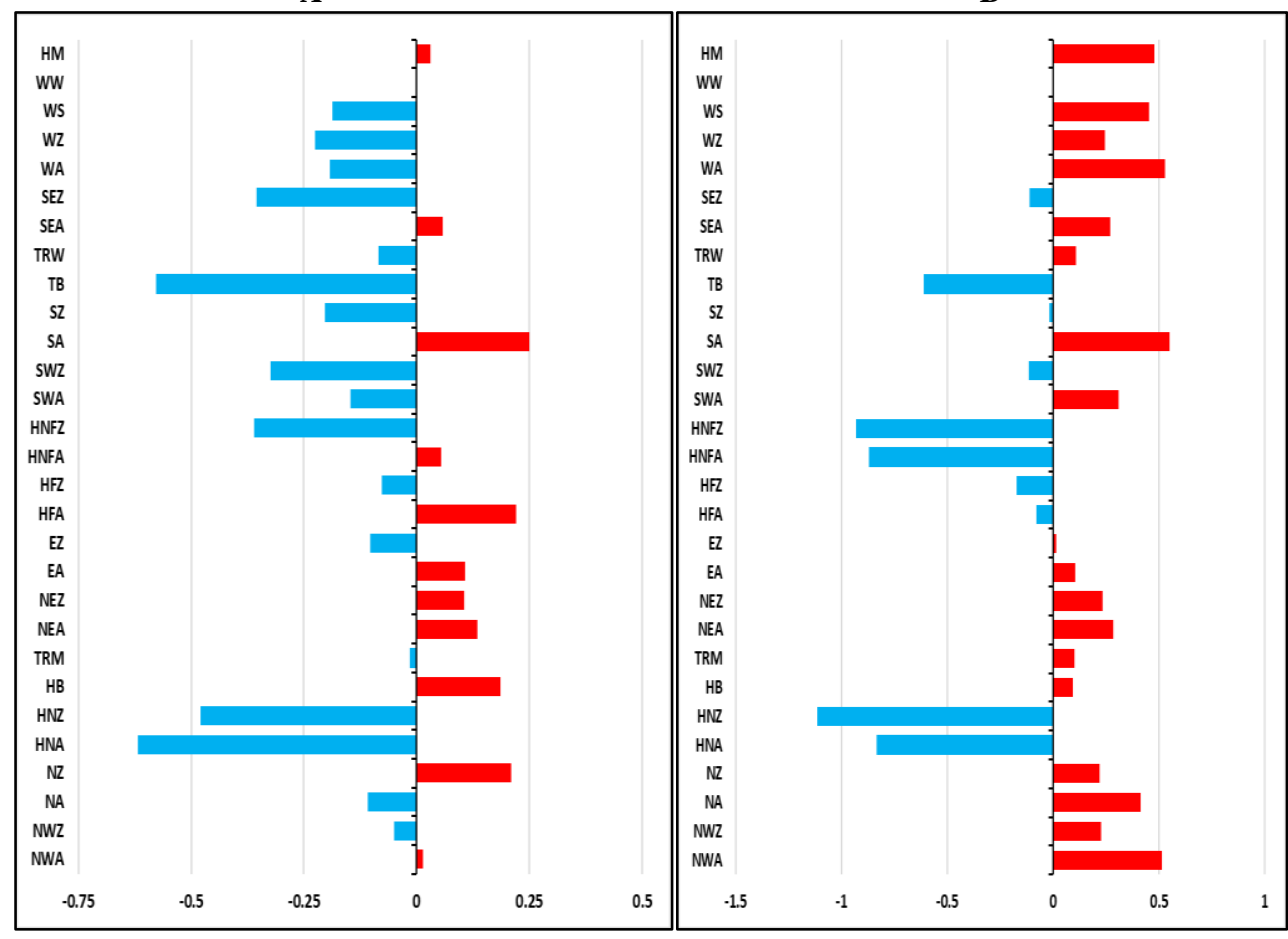

Figure 3. The warm semestrial correlation between HBGWL with NAO (A) and AO (B) In the Northern part of Moldavia during the 2000 to 2018 period 
is related to anthropogenic activities by increases the greenhouse gasses amounts into the atmosphere, which are feeling like feedback into the atmosphere-ocean-ice sea through the last decades (Serreze et al. 2007, 2009; Comiso et al. 2008; Schweiger et al. 2008; Kay et al. 2011). So, when the ice-sea in the Arctic area has shown a lower extent than the average, the negative phases of AO's activity prevailed while the positive $\mathrm{AO}$ phase is related to above normal sea-ice extent.

In the analyzed period (fig.3), a largely presence of the NAO's neutral or negative can be noticed. By NAO, there were associated the following types: SEZ: -0.4, TB: -0.7, SWZ: -0.3, HNFZ: -0.36, HNZ: -0.5, and HNA: -0.63. Instead, for $\mathrm{NAO}+$ types such as SA: 0.25, HB: 0.23, NZ: 0.24 .

\section{B. Cold semester}

During the cold semester, the NAO- is associated with the following types: TB: -0.6, HNFZ: -0.9, HNFA: -0.41, HFZ: -0.4, HNZ: -0.75, HNA: -0.66, and WS:

B

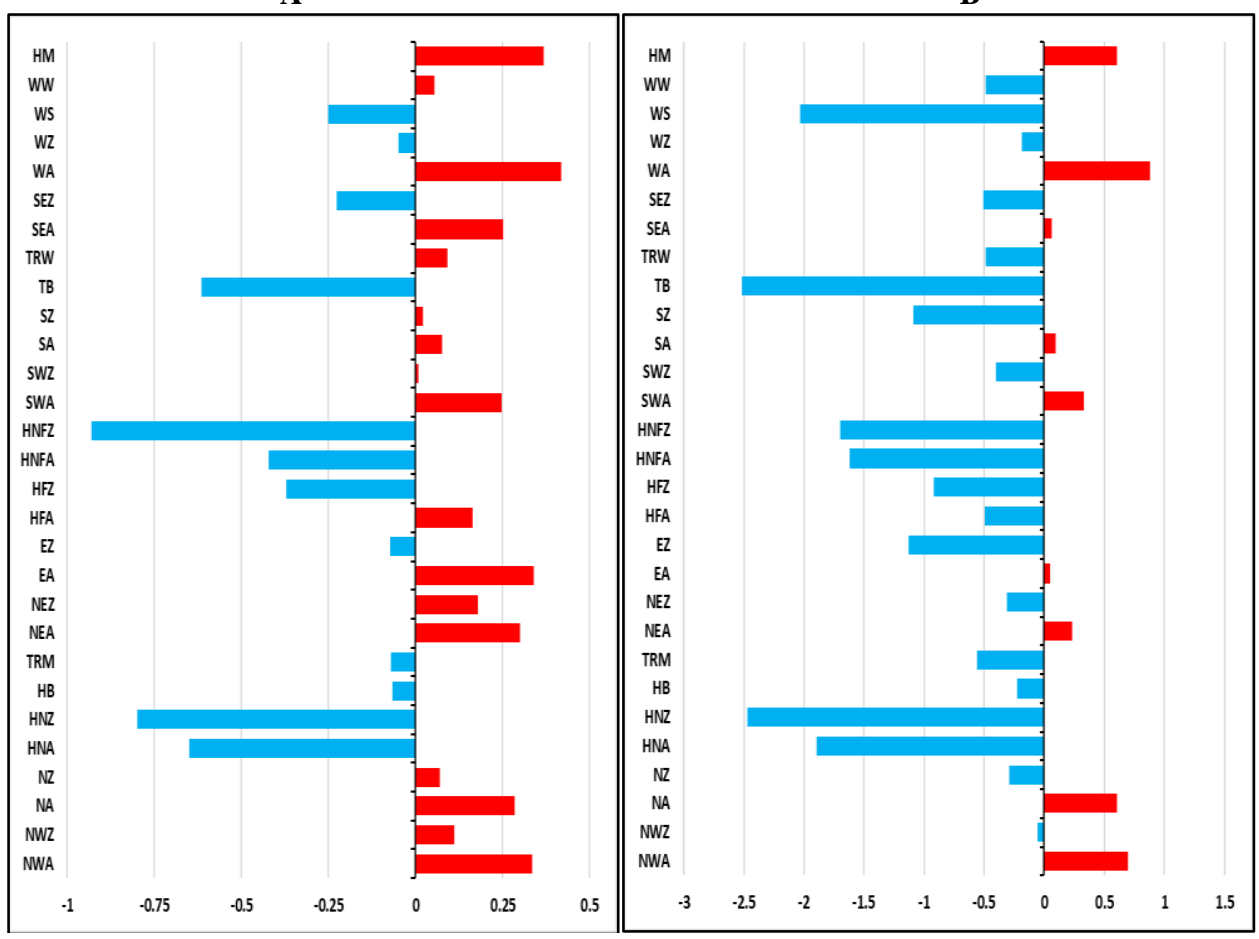

Figure 4. The cold semestrial correlation between HBGWL with NAO (A) and AO (B) In the Northern part of Moldavia during the 2000 to 2018 period 
-0.25. For NAO+, the most representative types are HM: 0.3, WA: 0.42, SEA: 0.25 , SWA: 0.25 , EA:0.29, and NWA: 0.3 (fig.4). The high intensity of NAO+ is given by the thermal gradient built between the sea surface temperature (SST) and the colder subpolar areas. As a result, there's an increase of the lows' rate over the northern part of the Northern Atlantic.

A decrease of the ice extent over the Arctic region has driven to a weakening of the AO. Therefore, during the cold semester, especially in the second half of winter when take place suddenly stratospheric warmings (SSW), the AO shows strong anomalies. (Pedatella et al. 2018).

Therefore, it can be noticed negative phases of $\mathrm{AO}$ are associated with the following of $\mathrm{HB}$ atmospheric patterns: WS: -2.0, TB: -2.5, SZ: -1.1, HNFZ: -1.6 , HFZ: 2.5, EZ: -1.2 , HNZ; -2.5 , and HNA: -1.91 . All of those are associated with a meridional air-masses movement over Europe. The negative phase of AO brings more of cyclonic conditions. In the case of AO, this fact will prevail these periods featured by significant rainfall amounts. Moreover, HNFA or HNA types are directly linked with the early (fall) and late (springtime) grass and ground frost in the studied area.

During the AO+, by the interest, the following types: HM: 0.37, WA: 0.41, NWA: 0.3 . At the same within the NAO+ scenario, the air-masses movement is associated with the zonal type where the rainfall amounts are weak or even nonexistent.

\subsection{Seasonal}

A good sight about these correlations is made when they come about their evolution during the seasonal level.

Therefore, once the atmospheric circulation gets more intense in the springtime, there can be noticed a positive phase of NAO. So, in the springtime, many types take place with a NAO+ phase in the background. NAO-'s few exceptions were associated with the following types: HNFZ: -0.39 , HNA: -0.76 , and HNZ: -0.3 . Those are associated with the winter's phenomena in the first half of spring, then, later, with the ground and grass frost occurrence. For AO, the same situation like that shown in the NAO's case is noticed.

For $\mathrm{AO}+$, the following atmospheric circulations are common: WA: 1.0, SA: 0.8, SWA: 0.72, EA: 0.98, NA: 0.9, NWA: 0.75, and for AO- types: TB: -1.0, HNFZ: -1.42, HNFA: -0.67, HNZ: -1.25, HNA: -1.28.

The summer is associated with an obvious decrease both at the low-pressure level placed over the northern part of the Atlantic and a thermal gradient between middle and polar latitudes. In this case, there can be noticed a predominance of the synoptic types featured by a negative phase of NAO. Also, the AO tend toward a neutral-weakly negative phase in the majority of types. 


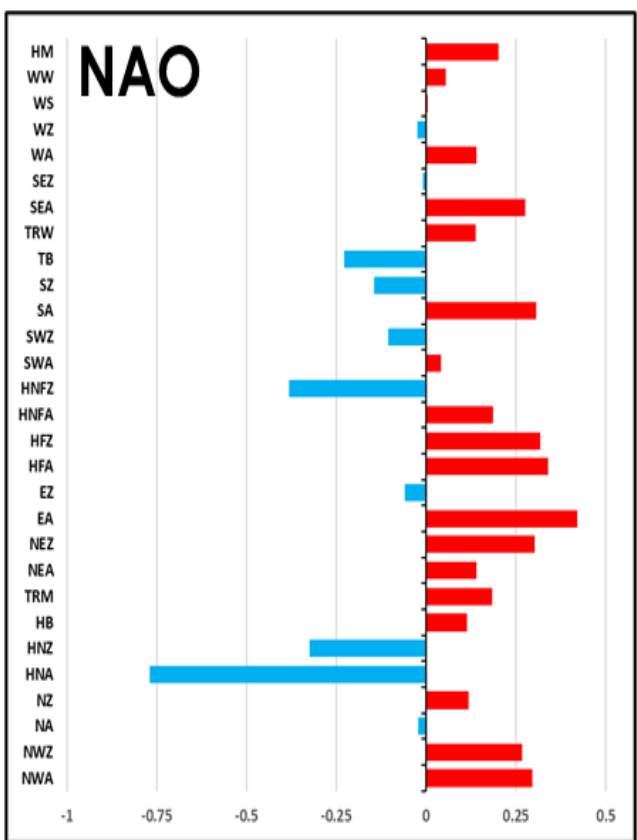

Spring

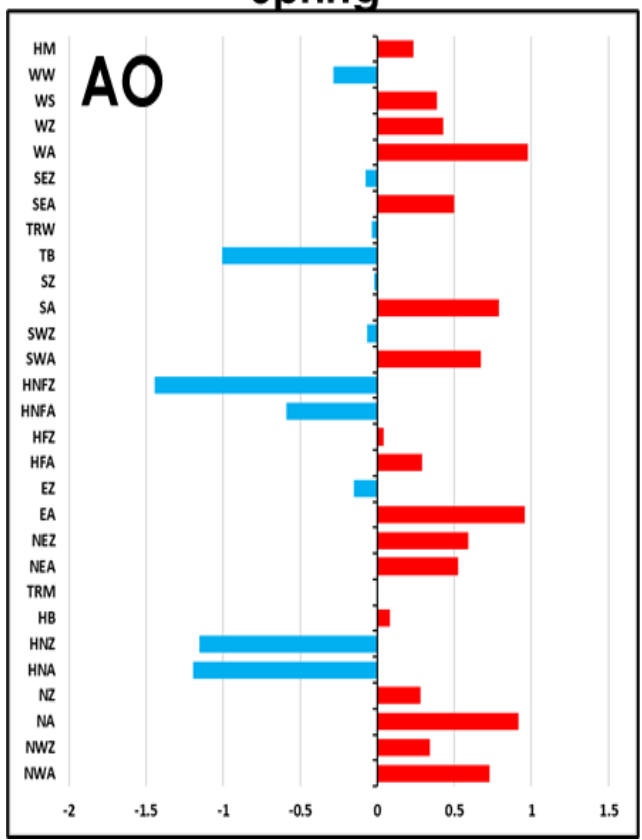

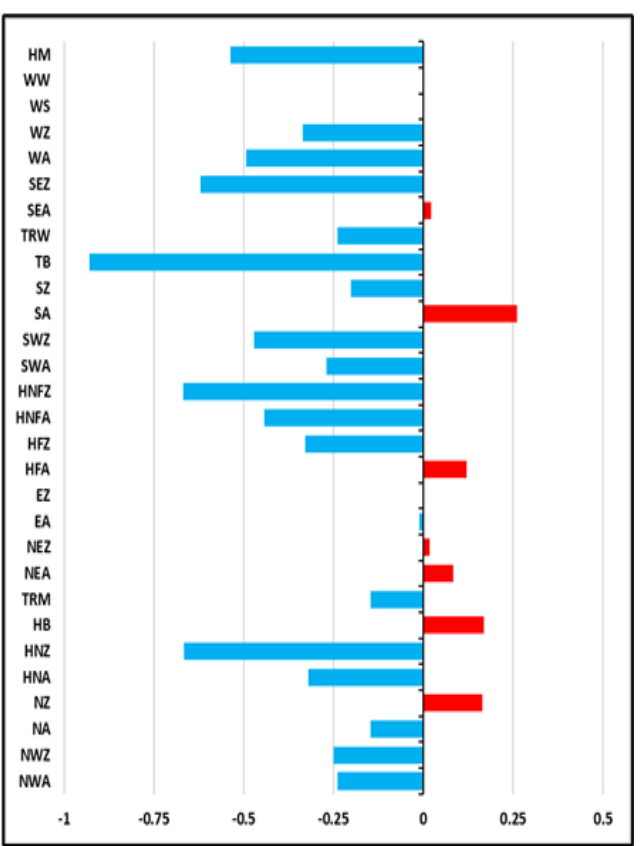

Summer

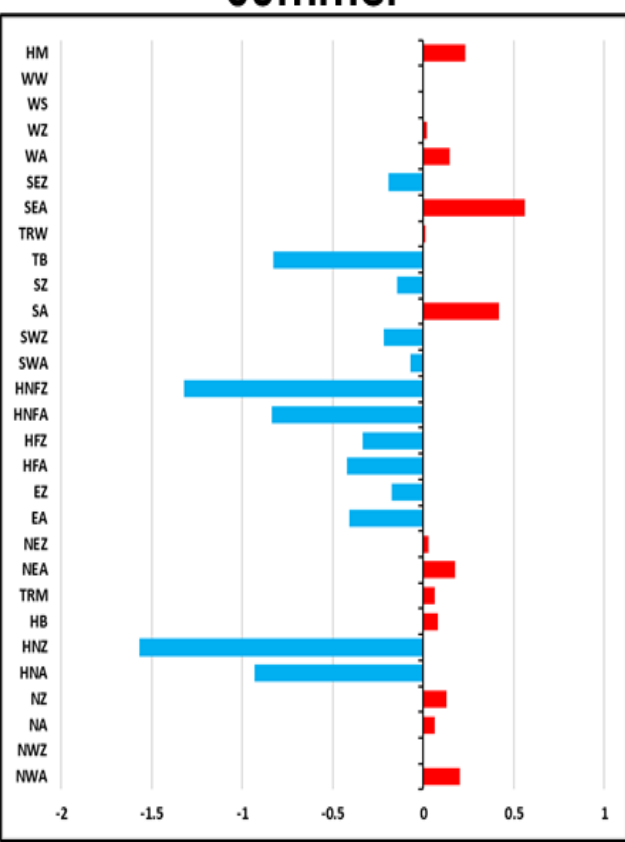



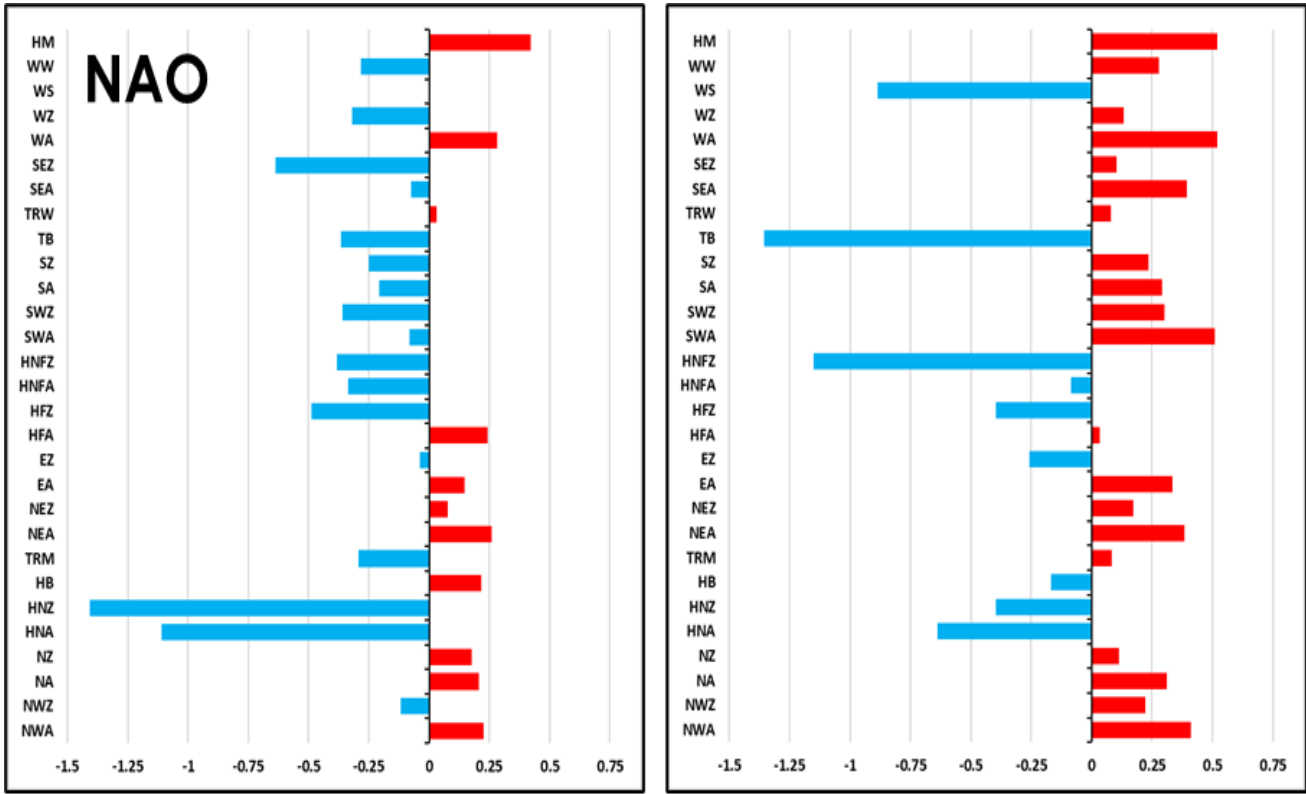

Fall

Winter
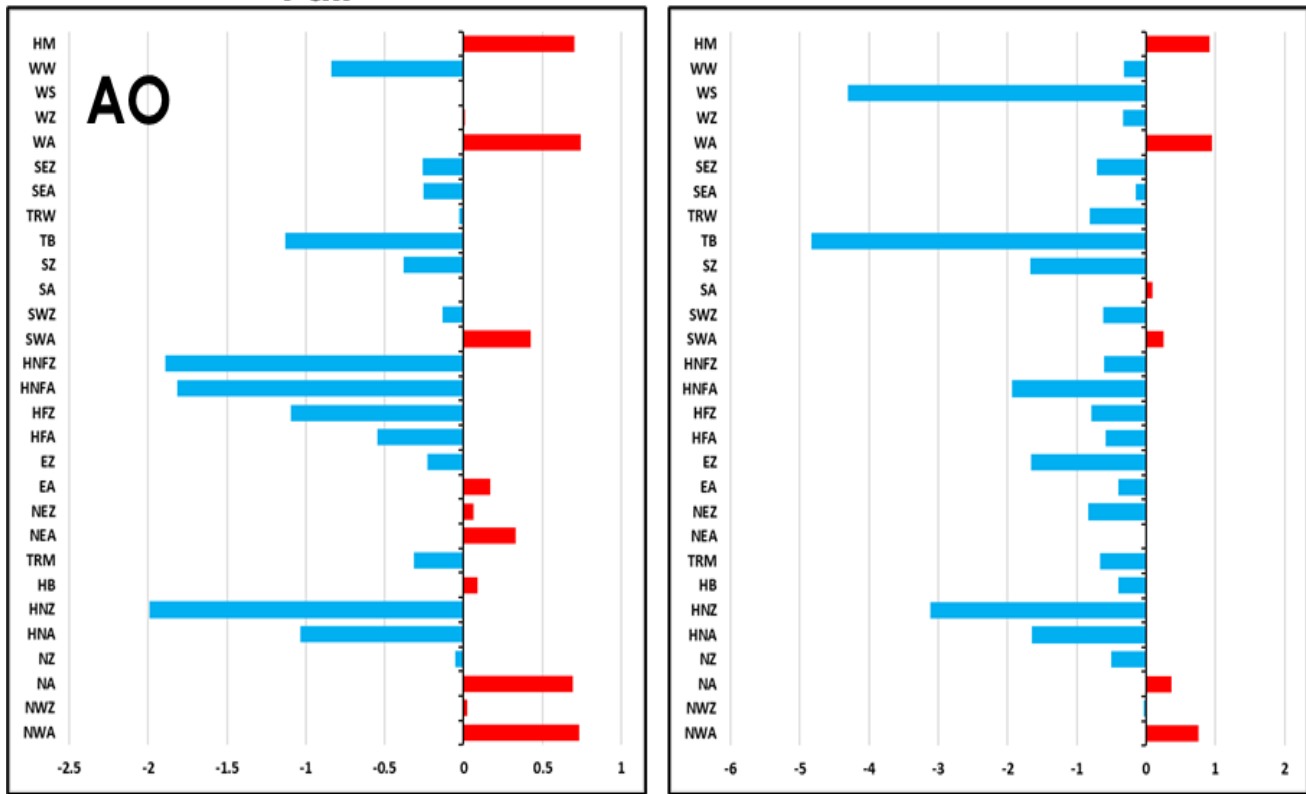

Figure 5. The seasonal correlation between HBGWL with NAO (A) and AO (B) In the Northern part of Moldavia during the 2000 to 2018 period 
A weakening phase of both NAO and $\mathrm{AO}$ is linked with a strengthening of the meridional air-mass movement. Due to a high energy rate in the system, there will be extreme weather events, such as storms and heavy rainfall in short time-periods.

In the fall, at least in the first half of it, the summertime features will show a continuity, both of the NAO and AO, respectively. In such conditions, a ridge will be established over the northern part of Europe. Therefore, beginning with the end of September, in the northern part of Moldavia, the ground frost can occur.

Furthermore, during October, increase the chances for important amounts of rainfall. Also, in October, associated with colder weather than monthly means, the rain can turn into sleet or even snow. As a result, a snow cover occurs not only in the highland but also in the lowlands.

In the wintertime, especially in the first half, there can be an increase in the number of synoptic types in NAO's positive phase. The fact is due to the latency heat of the water in comparison with the atmosphere. More accurately, the North Atlantic's warm water and the cold air-masses from the sub-polar area drives to a strengthening of the low-pressure areas around Iceland. In this way over Europe can be noticed an increased rate of westerlies. As a result, during the winter, the NAO+ is associate with the following types: HM: 0.53, WA: 0.51, SEA: 0.3, SWZ: 0.26, SWA: 0.5, and NWA: 0.41. For NAO-: WS: -0.81, TB: -1.3, HNFZ: -1.2, HFZ: -0.4 , HNA: -0.6 , and HNZ: -0.37 .

Associated with $\mathrm{AO}+$, the main types are HM: 0.9, WA:1.0, NWA 0.87, and for AO-: WS: -4.4, TB: -4.96, SZ: -1.8, HNFA: -1.95, EZ: -1.8, HNZ: -2.1, and HNA: -1.8 .

Associated with positive phase of NAO and AO, over a lot part of Europe take place air-mass movements what don't have a major impact regarding the weather. The shortage of precipitation associated with those types is the main factor for drought set up in the studied area. Instead, a range of extreme phenomena during the winter (huge amounts of snowfall, blizzards) are linked by atmospheric circulation types such as EZ, HNA, HNZ, HNFA, and HNFZ.

For a more suggestive sight regarding of all about brought into discussion in this paperwork, by the interest the following pictures which show the synoptic types at the continental's level by HBGWL and NAO/AO positive or negative phases. In fig. 6 (above), there are highlighted some aspects during the winter (cold semester) and summer (warm semester).

Therefore, in the wintertime (cold semester), when a high-pressure occur over the southern part of Europe (an 'Omega' shape ridge), there is a high risk for drought. Such weather patterns are associated with positive phases of NAO and AO. As a result, there will prevail the NWA, WA, and TRW atmospheric circulation types. When the phases of NAO and AO are negative, over the central and southern parts of Europe will occur lows associated with TRM, NEZ, and EZ 


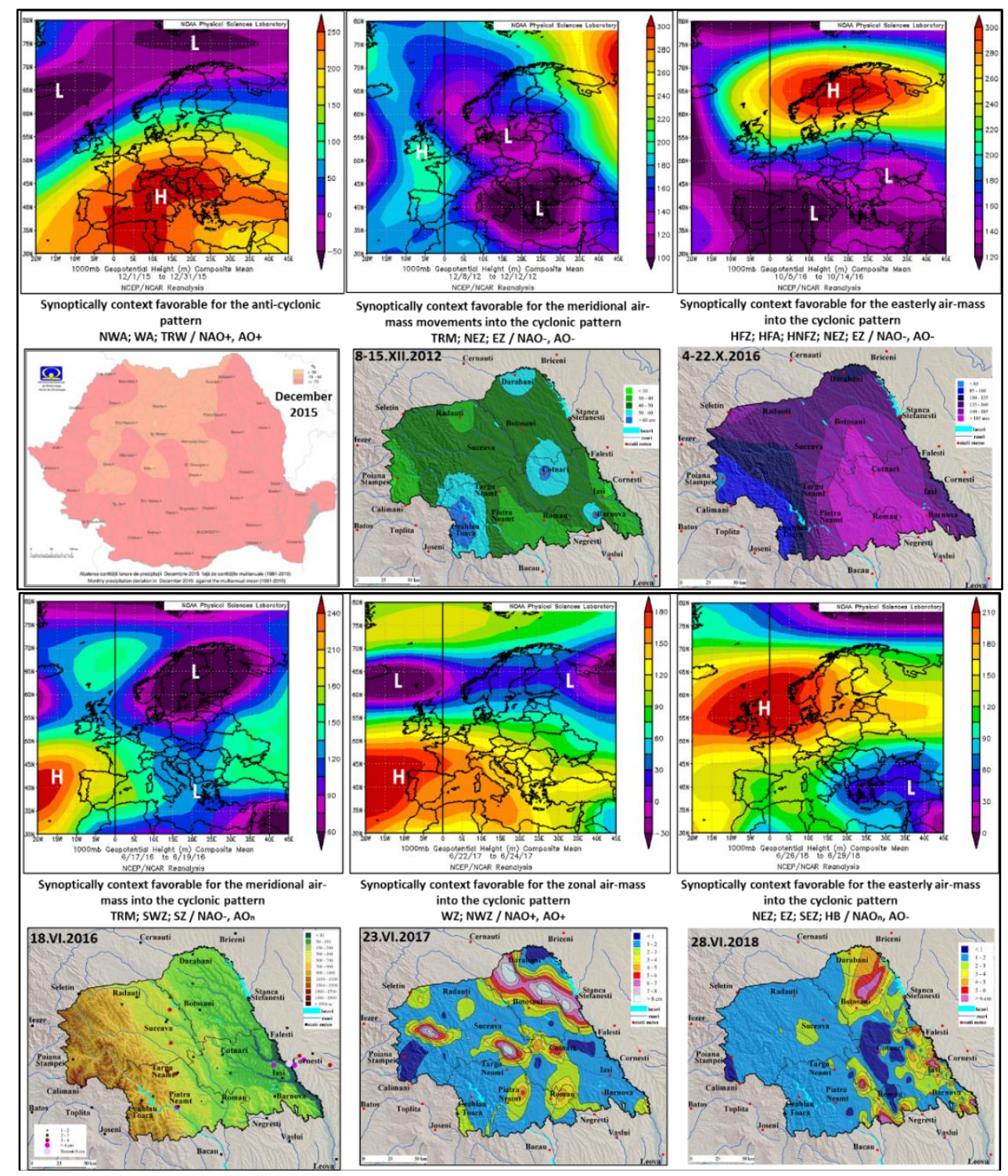

Figure 6. The linkage between some synoptically types with representative rainfall in the northern part of Moldavia (H-High, L-Low pressure). The maps with the hail's spread (below picture, last two from right) use the parameter's values into the maximum reflectivity of convective clouds (Cumulonimbus). Take into account only the values which exceed $1 \mathrm{~cm}$ in diameter. 
atmospheric circulations. Meanwhile, in the northern part of Europe, high-pressure areas are associated with HFA, HFZ, and HNFZ atmospheric circulation types.

During the warm period (especially in the summertime), there is a high risk for large hailstone in Moldavia's northern part when the zonal circulations occur. Such situations occurred on June the $18^{\text {th }}$, 2016, and June the $23^{\text {rd }}, 2017$. Then, at the continent's level prevailed TRM, SWZ, SZ, WZ, and NWZ atmospheric circulation types. Instead, when the SEZ, EZ, NEZ atmospheric circulation types occurred, the risk of high hailstones at ground level was much lower but has increased the risk of intense rainfall associated with flash floods. In contrast with the cold semester, it couldn't be established a direct association with positive or negative NAO/AO phases with weather patterns during the warm semester.

A summarize all the atmospheric circulation associated with $\mathrm{NAO}+/$ - and $\mathrm{AO}$ $+/$ - for the entire time period 2000 to 2018 in the northern part of Moldavia, shown in table 1.

Table 1. The linkage between HBGWL types with the positive/negative phases of NAO/AO in the northern part of Moldavia between 2000 to 2018

\begin{tabular}{|c|l|l|l|l|}
\hline Type & \multicolumn{1}{|c|}{ NAO+ } & \multicolumn{1}{|c|}{ NAO- } & \multicolumn{1}{|c|}{ AO+ } \\
\hline Annual & HM, EA, NEA, NWA & $\begin{array}{l}\text { SEZ, TB, HNFZ, HNZ, } \\
\text { HNA }\end{array}$ & HM, WA, NA, NWA & WS, TB, HNFZ, HNFA, HNZ, HNA \\
\hline Warm season & SA, HFA, HB, NZ & $\begin{array}{l}\text { SEZ, TB, SWZ, HNFZ, } \\
\text { HNZ, HNA }\end{array}$ & HM, WS, WA, SA, NWA, NA & TB, HNFZ, HNFA, HNZ, HNA \\
\hline Cold season & $\begin{array}{l}\text { HM, WA, SEA, SWA, } \\
\text { EA, NEA, NA, NWA }\end{array}$ & $\begin{array}{l}\text { WS, TB, HNFZ, HNFA, } \\
\text { HFZ, HNZ, HNA }\end{array}$ & HM, WA, NA, NWA & $\begin{array}{l}\text { WS, TB, SZ, HNFZ, HNFA, HFA, } \\
\text { HFZ, EZ, TRM, HNZ, HNA }\end{array}$ \\
\hline Spring & $\begin{array}{l}\text { HM, SEA, SA, EA, } \\
\text { NWZ, }\end{array}$ & TB, HNFZ, HNZ, HNA & WA, EA, NEZ, NA, NWA & TB, HNFZ, HNFA, HNZ, HNA \\
\hline Fall & $\begin{array}{l}\text { SA } \\
\text { NWA, NA HFA, NEA, }\end{array}$ & $\begin{array}{l}\text { HM, WZ, WA, TB, SWZ, } \\
\text { WNFZ, HNFA, HFZ, HNZ, NWA, NWZ }\end{array}$ & SEA, SA & TB, HNFZ, HNFA, HNZ, HNA \\
\hline Winter & $\begin{array}{l}\text { HM, WW, WA, SEA, } \\
\text { SA, SWZ, SWA, NWA }\end{array}$ & WS, TB, HNZ, HNA, HNZ & HM, WA, NWA & $\begin{array}{l}\text { WW, TB, HNFZ, HNFA, NEZ, } \\
\text { HNA, HNZ }\end{array}$ \\
\hline
\end{tabular}

\section{CONCLUSIONS}

The linkage between HBGWL types with the positive and negative phases of $\mathrm{NAO} / \mathrm{AO}$ has highlighted that the westerlies (NAO, WA) are associated exclusively with $\mathrm{NAO}+/ \mathrm{AO}+$. The negative phases of NAO/AO are following by HNFZ, HNA, HNZ, and TB types.

The westerly types aren't associated with exceptional phenomena regarding the pluvial aspect. However, the prolonged periods characterized by rainfall shortage during of cold semester can set up the drought. 
The synoptic patterns associated with the negative phase of NAO or AO can set up extreme weather events, such as huge amounts of rainfall/snowfall or blizzards.

ACKNOWLEDGMENT: This work was co-funded by the European Social Fund, through Operational Programme Human Capital 2014-2020, project number POCU/380/6/13/123623, project title 'PhD Students and Postdoctoral Researchers Prepared for the Labour Market'

\section{References}

Apostol, L., Sfîcă L. (2013), Thermal differenciations induced by the Carpathian Mountains on the Romanian territory, Carp J Earth Environ Sci vol. 8(2), p.215 to 221. [link]

Bartholy, J., Pongracz, R., Gelybó, Gy. (2009), Climate signals of the North Atlantic Oscillation detected in the Carpathian Basin. Applied Ecology and Environmental Research, vol. 7 (3), p. 229 to 240. DOI: https://doi.org/10.15666/aeer/0703_229240

Baur, F., Hess, P., Nagel, H. (1944), Kalendar der Grosswetterlagen Europas 1881-1939, Bad Homburg (DWD).

Bordei-Ion, N. (1988), Fenomene meteoclimatice induse de configurația Carpaților în Câmpia Română, Ed. Academiei Române, București, România, p.224.

Cash, B. A., Lee, S. (2001), Observed nonmodal growth of the Pacific-North American teleconnection pattern, J. Climate, 14, 1017-1028, doi: https://doi.org/10.1175/15200442(2001)014<1017:ONGOTP>2.0.CO;2

Comiso, J. C., Parkinson, C. L., Gersten, R., Stock, L. (2008), Accelerated decline in the Arctic sea ice cover, Geophys. Res. Lett., vol. 35, L01703, doi: https://doi.org/10.1029/2007GL031972

Feldstein, S. B. (2000), The timescale, power spectra, and climate noise properties of teleconnection patterns, J. Climate, vol. $13, \quad$ p. 4430 to 4440, doi: https://doi.org/10.1175/1520-0442(2000)013,4430:TTPSAC.2.0.CO;2

Hess, P., Brezowsky, H. (1952), Katalog der Grosswetterlagen Europas. Berichte des Deutschen Wetterdienstes in der US-Zone, No. 33.

Hurrell, J.W. (1995), Decadal trends in the North Atlantic oscillation regional temperatures and precipitation, Science No. 269: p. 676 to 679, DOI: https://doi.org/10.1126/science.269.5224.676

Hurrell, J.W., Kushnir, Y., Ottersen, G., Visbeck, M., Eds. (2003), The North Atlantic Oscillation Climate Significance and Environmental Impacts, Geophysical Monograph Series, 134. American Geophysical Union, Washington DC.

Johnson, N. C., Feldstein, S. B. (2010), The continuum of North Pacific sea level pressure patterns: Intraseasonal, interannual, and interdecadal variability, J. Climate, 23, 851-867, doi: https://doi.org/10.1175/2009JCLI3099.1

Kay, J. E., Holland, M. M., Jahn, A. (2011), Inter-annual to multi-decadal Arctic sea ice extent trends in a warming world, Geophys. Res. Lett., No. 38, L15708, doi: https://doi.org/10.1029/2011GL048008

Lopez-Moreno, J.I., Vicente-Serrano, S.M. (2008), Positive and negative phases of the wintertime north Atlantic oscillation and drought occurrence over Europe: A 
multitemporal-scale approach, Journal of Climate No. 21: p. 1220 to 1243 , DOI: https://doi.org/10.1175/2007JCLI1739.1

Nakamura, T., Yamazaki, K., Iwamoto, K., Honda, M., Miyoshi, Y., Ogawa, Y., Ukita, J. (2015), A negative phase shift of the winter AO/NAO due to the recent Arc tic seaice reduction in late autumn, J. Geophys. Res. Atmos., 120,3209-3227, doi: https://doi.org/10.1002/2014JD022848

Osborn, T.J. (2006), Recent variations in the winter North Atlantic Oscillation, Weather vol. 61: p. 353 to 355, DOI: https://doi.org/10.1256/wea.190.06

Pedatella, N., Schmidt, H., Chau, J., Goncharenko, L.P. C. Stolle, Hocke, K., Harvey, V. L., Funke, B., Siddiqui T. A. (2018), How sudden stratospheric warmings affect the whole atmosphere, Earth \& Space Science News, No. 99, p. 35 to 38. DOI: https://doi.org/10.1029/2018EO092441

Scaife, A.A., Knight, J.R., Vallis, G.K., Folland, C.K. (2005), A stratospheric influence on the winter NAO and North Atlantic surface climate, Geophysical Research Letters vol. 32: L18715, doi: https://doi.org/10.1029/2005GL023226.

Schweiger, A. J., Lindsay, R. W., Vavrus, S., Francis, J. A. (2008), Relationships between Arctic sea ice and clouds during autumn, J. Clim., vol. 21, p. 4799 to 4810, DOI: https://doi.org/10.1175/2008JCLI2156.1

Serreze, M.C., Carse, F., Barry, R.G., Rogers, J.C. (1997), Icelandic low activity: climatological features, linkages with the NAO, and relationships with recent changes in the Northern Hemisphere circulation, Journal of Climate vol. 10: p. 453 to 464, DOI: https://doi.org/10.1175/1520-0442(1997)010<0453:ILCACF>2.0.CO;2

Serreze, M. C., Holland, M. M., Stroeve, J. (2007), Perspectives on the Arctic's shrinking sea ice cover, Science, vol. 315, p. 1533 to 1536, DOI: https://doi.org/10.1126/science. 1139426

Serreze, M. C., Barrett, A. P., Stroeve, J. C., Kindig, D. N., Holland, M. M. (2009), The emergence of surface-based Arctic amplification, Cryosphere, vol. 3, p. 11 to 19. [link]

Thompson, D.W. J., Wallace, J.M. (1998), The Arctic Oscillation signature in the wintertime geopotential height and temperature fields, Geophys. Res. Lett., No. 25, p. 1297 to 1300, doi: https://doi.org/10.1029/98GL00950

Trigo, R.M., Osborn, T.J., Corte-Real, J.M. (2002), The North Atlantic Oscillation influence on Europe: Climate impacts and associated physical mechanisms, Climate Research No 20: p. 9 to 17 [link]

van Loon, H., Rogers, J. (1978), The seesaw in winter temperature between Greenland and northern Europe. Part I: general descript, Monthly Weather Review 106: p. 296 to310 DOI: https://doi.org/10.1175/1520-0493(1978)106<0296:TSIWTB>2.0.CO;2

Wanner, H., Brönnimann, S., Casty, C., Gyalistras, D., Luterbacher, J., Schmutz, C., Stephenson, D.B., Xoplaki, E. (2001), North Atlantic Oscillation - concepts and studies, Surveys in Geophysics vol. 22: p. 321 to 381. DOI: https://doi.org/10.1023/A:1014217317898

*** (1969), Katalog der Grosswetterlagen Europas, 2. neu bearbeitete und erg€anzte Aufl. Berichte des Deutschen Wetterdienstes 113. Offenbach am Main. 
*** (1977), Katalog der Grosswetterlagen Europas 1881-1976, 3. verbesserte und erg€anzte Aufl. Berichte des Deutschen Wetterdienstes 113. Offenbach .am Main.

www.meteoromania.ro

www.wetter3.de

https://www.noaa.gov/

(C) 2020 by the authors. Licensee UAIC, Iasi, Romania. This article is an open access article distributed under the terms and conditions of the Creative Commons Attribution (CC BY-NC-ND) license (https://creativecommons.org/licenses/by-nc-nd/4.0). 